\title{
论高校校园地下空间的综合利用 一种可持续的校园空间发展模式
}

\section{Discussion on Comprehensive Utilization of Underground Space in University Campus: A Sustainable Mode for Campus Space Development}

摘要: 高校数量的激增和学生人数的扩容使得高校校园的规划设计和研究也进 入了空前繁荣期。综合国外高校的建设和发展历程和经验来看，未来我国高校 校园地下空间开发利用应重视校园容量扩充、功能复合性、地下连通性以及高 效联络性四方面。通过合理开发地下空间、整合校园空间功能，能够使校园获 得更为丰富的空间资源，促进空间的集约化利用，改善校园地面空间的生态环 境和交通环境, 有利于实现校园土地、服务设施、基础设施等资源的共享, 降 低校园运行的能源和资源成本, 提高高校校园空间发展的可持续性。

Abstract: The plan, design and research of university campus are now in a prosperous period along with the increase of number of universities and college students. Viewing from the progress and experience of subterranean space development in college and university campus overseas and domestic, more focus should be put on increase of campus space volume, functional recombination, underground connectivity and effective connectedness in the progress of belowground space utilization in domestic university campuses in the future. Through rational utilization of underground space and recombination of campus spatial functions, campus spatial resources will be more abundant, campus spatial intensive utilization will be improved, ecological and communicant environment of ground space will be ameliorated, share of land resources, service facilities and infrastructures will be made better, energy consumption of campus operation will be lowered, and sustainability of campus spatial development will be raised.

关键词：高校校园；地下空间；综合利用；可持续发展；模式

Keywords: University Campus; Underground Space; Comprehensive Utilization; Sustainable Development; Pattern

“十二五”国家科技支撑计划项目“城市地下空间开发应用技术集成与示范” (2012BAJ01B00)，2015 年度教育部人文社会科学研究规划基金项目“现代 城市地下空间的规划、控制与设计研究”（15YJA760058）共同资助

作者: 赵景伟, 山东科技大学土木工程与建筑学院, 副教授; 同济大学地下空间 研究中心, 博士后。zjwzbt@126.com

彭建，同济大学地下空间研究中心，博士研究生。pengjiantj@hotmail.com 彭芳乐, 博士, 同济大学地下空间研究中心, 教授、博导。 pengfangle@tongji.edu.cn
1998 年我国高等教育在校生为 340.9 万人, 1999 年开始进行大规模扩招, 根据《中国统计年鉴 2013》 的数据, 截止到 2012 年底, 普通高等学校数量达到 2442 所, 普通高校在校学生数为 2536.6 万人, 2011 年高等教育毛人学率（18 22 周岁）达到 $26.9 \%$ 。在 1998-2006 年近 8 年的大规模扩招过程中, 各高校先 后都出现了空间过小和用地资源短缺的局面, 办学规 模的快速发展大大超过校园面积的增长速度，各类教 育资源严重超负荷运转, 对许多高校校园用地扩张提 出了必然的要求。

\section{1 高校校园空间拓展概述}

随着高校数量的激增和学生人数的增长, 高校校 园的规划设计和研究也进人了空前繁荣期。高校校园 规划结束了以往“渐进式” 发展格局, 跨越到 “一次 性” 整体设计模式 ${ }^{[1]}$ 。自 1998 年位于河北廊坊经济技 术开发区的东方大学城开工建设以来, 到 2006 年全国 共建设大学城 64 座。其中广州大学城面积 $34.4 \mathrm{~km}^{2}$, 到 2014 年, 进驻广州大学城 10 所高校的学生数量达 到 16 万多人 ${ }^{[2]}$ 。大学城作为一个新的城区和城市功能 组团, 是大学校园用地扩张和城市发展的结果, 成为 多核心城市的重要的组成部分, 对城市的空间结构产 生重大的影响 ${ }^{[3]}$, 表现为大规模的新校区建设热潮, 出现了巨型化、生态化、城市化、信息化、郊区化的 形态及功能特征 ${ }^{[4]}$, 许多高校出现了新校区与校本部 之间二元甚至三元的空间形态关系。

传统意义上的校园空间拓展, 是通过突破原有用 地界线或另辟城市土地建设完成的，这种情况下的校 园布局多采用以下方式：传统式（功能分区）、组团式 (团组建筑群)、核心式（图书馆和教学主楼等作为校 
园中心核)、再生式 (就地再开发)、有机增长式（统一规划 分期实现）、鱼骨式（鱼脊状主干道串联校园）、园林式（灵 活布局注重生态环境）、自由式（注重实际地形与环境的规 划布局特点）等。

随着城市用地的日益紧张, 针对大多数校园用地不可无 限扩张的特点, 近年来高校校园空间拓展方式已由早期的粗 放开发型逐渐转向精细利用型, 即发展集中紧凑型的校园空 间, 更多强调校园用地的利用效益最大化, 如香港城市大学、 香港理工大学、新加坡南洋理工大学、希腊塞萨洛尼基亚里 士多德大学等。

对大学校园进行主动的立体式规划设计, 不仅具有重要 的现实意义, 还具有深远的历史意义 ${ }^{[5]}$ 。因此, 我国各高校应 该深人挖掘老校园内部空间，借鉴世界其他国家和地区大学校 园建设的经验, 适当控制新校园的用地和建设规模, 通过向空 中和地下空间拓展，创造校园空间的三维空间形态关系。

\section{2 高校校园地下空间开发目的及功能}

\section{1 地下空间开发目的}

校园除了为城市提供教学、科研、避难等物质空间以外, 还提升了城市的精神文化品质 ${ }^{[6]}$ 。在发展过程中, 许多高校 原有的校园及各类建筑的规模与不断增长的教学科研需求不 相适应, 需要扩建, 但校园的扩建往往受到城市空间和建筑 风貌要求的限制, 因此, 采用向地下拓展空间, 解决新老建 筑结合的问题成为众多高校的选择，体现了校园空间立体规 划、可持续发展的重要思想，如美国加州大学伯克利分校、 哈佛大学、伊利诺伊大学、密执安大学的地下或半地下图书 馆, 美国明尼苏达大学土木与矿物工程系新馆, 日本同志社 大学 (Doshisha University) 图书馆新馆, 香港理工大学地下 大礼堂等。韩国暻园大学在 2010 年建成的地下校园 “未来 馆”, 地上 7 层, 地下 4 层, 总建筑面积 6.9 万 $\mathrm{m}^{2}$, 其中地 下建筑面积 4.4 万 $\mathrm{m}^{2}$, 包括 61 个教室、 7 个研讨室以及若 干阅览室和实习室, 能容纳 4700 多人, 通过一个大型庭院 将地下三层与地铁车站相连。

当然, 国外高校地下空间开发利用的目的也表现在其他 几个方面 : 有的以扩大校园地面空间、改善环境或保护原有 环境为主, 为校园提供大量使用空间及绿化空间——如由多 米尼克·佩罗 (Dominique Perrault) 建筑师事务所设计的韩 国梨花女子大学（Ewha Womans University）校园中心 ; 有 的是为了适应当地气候的特点或特殊科研与教学需要而将高 校功能的一部分转人地下空间——如悉尼科技大学地下图书 馆、北京化工大学东校区地下礼堂、暨南大学学校新校区的 “学生一食堂”、“图书馆大楼”、“教学大楼”项目等; 有的 是以改善地面交通为主, 为校园提供便捷的动态交通设施以
及停车设施一一如上海科技大学的校园地下环路系统以及地 下停车系统, 中山大学南校区西侧球场下的大型地下停车场 (可提供机动车位 1678 个) ; 有的是为了实现空间的流动 与开放性, 促进地面建筑在地下的连通一如台北实践大学 体育馆及图资大楼。

\section{2 地下空间开发功能}

高校校园已经成为城市新的空间增长节点, 地下空间的 开发利用符合城市空间集约化利用的整体发展趋势, 新的地 下空间功能不断涌现, 地下空间开发规模也越来越大。结合 国内外高校校园地下空间发展特点, 地下空间开发的功能主 要体现在以下方面。

- 地下停车设施：这是当前应用最广的地下空间利用类 型, 满足校园内不断增长的机动车和自行车停车需求, 可结 合校园绿地、建筑单体的地下空间、广场和操场等进行地下 空间规划建设；

- 地下道路系统 : 包括步行系统和车行系统, 可以改善 师生步行环境, 减少人车混行的状况, 使校园交通顺畅、安 全, 改善生态环境;

- 地下公共服务系统 : 包括邮政、银行、食堂、美食店、 商店、咖啡店、快递、药店、书店、美容店、休闲娱乐等, 满足师生的日常生活需求, 提升学校公共服务能力, 改善校 园文化活动氛围。这一类系统空间数量多、类型复杂, 应做 好各种功能的协调与整合；

- 地下体育健身设施 : 结合高校当地的自然与气候环境, 开发单建或附建式的地下体育场馆或小型体育健身设施, 如 游泳馆、健身馆、乒乓球或羽毛球场馆等;

- 地下会堂或礼堂 : 地下空间具有冬暖夏凉的优越性, 冬季可通过被动式集热系统解决采暖需求, 夏季也较容易满 足适宜温度的要求, 但是由于聚集大量人流要做好防灾措施;

- 地下教学与办公设施 : 一般是地面建筑在地下的空间 及功能延续, 可作为教室、自习室、图书馆藏书室、实验室、 阅览室、会议室、医学院标本室、文印室以及仓库等, 对于 有特殊要求的实验室要考虑单独开发建设;

- 地铁车站 : 满足高校大量人流的交通出行需要, 大学 城则可以依据城市总体规划选址在某个校园内或几个校园之 间的用地, 结合地铁站的建设可以通过下沉庭院及下沉广场 连通校园其他类型的地下空间。

\section{3 国内外高校地下空间的综合利用}

\section{1 梨花女子大学校园中心}

2008 年 5 月, 由多米尼克 ·佩罗建筑师事务所设计的梨 花女子大学校园中心建成投人使用。校园中心依山就势, 顶 
部覆土后处理成绿地。总建筑面积 6.9 万 $\mathrm{m}^{2}$, 能够容纳 2 万 学生在其中学习、健身与交流 (图 1一图 3)。校园中心地下 共 6 层, 接近地面的 4 层为阅览室、阶梯教室、剧场、会议 室及健身中心, 下面的 2 层为能够停放 750 辆车的停车场。 该校园中心不仅达到了扩大校园使用空间和节能的目的, 而 且实现了校园的立体绿化, 丰富了首尔市中心的绿色空间。

\section{2 芝加哥大学曼索托图书馆}

芝加哥大学曼索托图书馆 (Joe and Rika Mansueto Library）设计有地下自动储藏和检索系统（ASRS: Automatic Storage and Retrieval System), 共收藏 350 万本图书。在地 面上看, 其外观像是一颗镶嵌在地面的水晶球, 高性能低辐 射烧结玻璃穹顶覆盖了藏书空间, 为 $57 \%$ 的空间阻挡了阳 光, 减少了 $73 \%$ 的光照热量, 同时还能够引人 $50 \%$ 的光线 (图 4一图 6)。曼索托图书馆的所有图书都放在地下, 因为 地下空间的温度和湿度环境更好控制, 能够有效地节约成本。

进人图书馆的读者只需通过电脑登录图书馆网页, 搜寻 所要书籍, 馆内经过特殊设计的机械手臂就能将所选书籍挑 出来, 读者会收到简讯通知, 在 5 分钟之后就可以到前台领 取。还书时只需要扫描一下书上条码放在书筐里, 剩下的事 情由机械手臂完成, 这样一来不仅降低了图书管理的时间和 人力成本, 极大提高了借书还书的效率, 还使图书得到了非 常好的保存, 减少了图书的破损率。

\section{3 明尼苏达大学土木与矿物工程系新馆}

土木与矿物工程系新馆主要由行政办公室、实验室和教 室三大部分组成, 其建设目的主要是为了保护大学校园地面 上原有的建筑风格, 保留地面有限的开敞空间, 更好地解决 建筑与环境、建筑与能源等重大问题, 创造新的空间和环境。 新馆采用了全地下方案, 总建筑面积 1.41 万 $\mathrm{m}^{2}$ ( $95 \%$ 在地下), 其中有 1 万 $\mathrm{m}^{2}$ 建于土层中, $4100 \mathrm{~m}^{2}$ 建在砂岩层中, 上下 两部分之间由两个坚井内设楼梯和电梯联系。主要出人口设 在东、西两部分的过渡处, 也是下沉广场的最低点, 人们由 广场从水平方向进人地下建筑, 与进人一般的地面建筑并无 区别。对地下建筑及其地上部分, 不是采取掩盖的方法, 而 是在保留开敞空间和原有校园风貌的前提下, 充分展示采用 新技术而产生的新建筑形象（图 7, 图 8) ${ }^{[9]}$ 。土木与矿物工 程系新馆在规划、设计、节能方面进行了全面研究, 综合展 示了地下空间开发的最新技术，揭示了地下空间利用的巨大 潜力。

\section{4 台北实践大学体育馆及图资大楼}

台北实践大学体育馆及图资大楼基地西侧为北安路 501 巷, 东临大直街 48 巷, 北面及南面区域为学校既有的建成 区域, 基地面积 4.2 万 $\mathrm{m}^{2}$ (图 9)。图资大楼、体育馆分别 位于基地的东部、西部, 总建筑面积约 2.7 万 $\mathrm{m}^{2}$, 建成于 2009 年 9 月。图资大楼（图 10）和体育馆之间通过地下艺

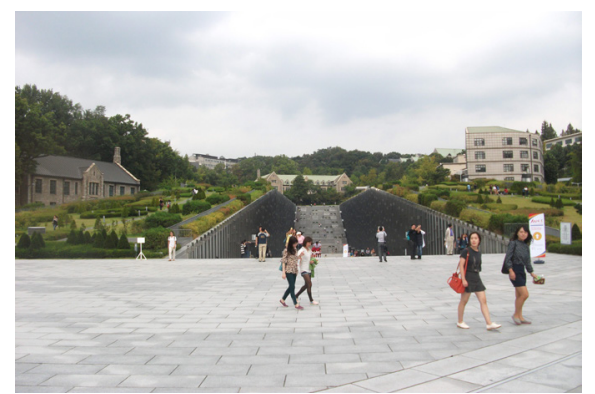

图 1 韩国梨花女子大学校园中心 资料来源 : 赵景伟 摄

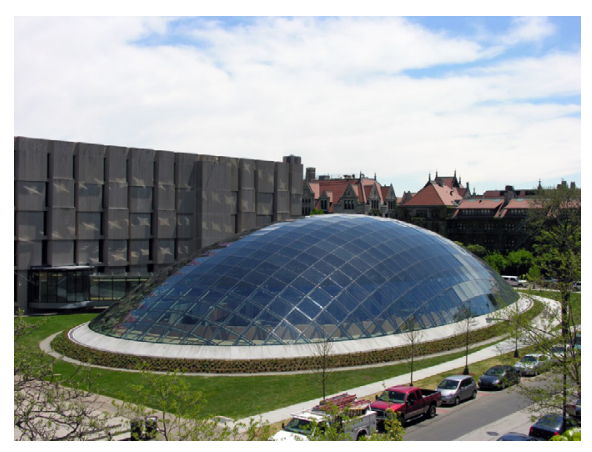

图 4 图书馆地面外观 资料来源 : 参考文献 [7]

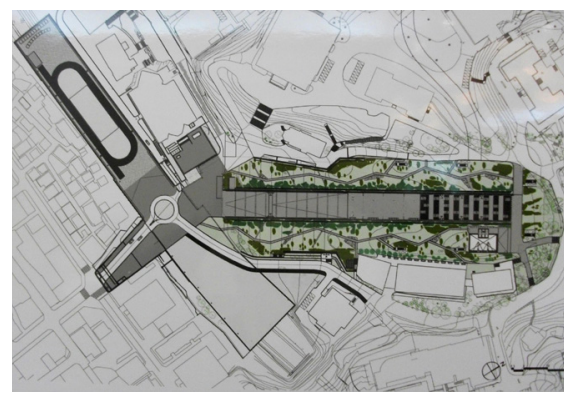

图 2 韩国梨花女子大学校园中心设计总平面 资料来源: 赵景伟 摄于第 14 届国际地下空间联合研究中 心年会 (ACUUS 2014) 会议宣传展示

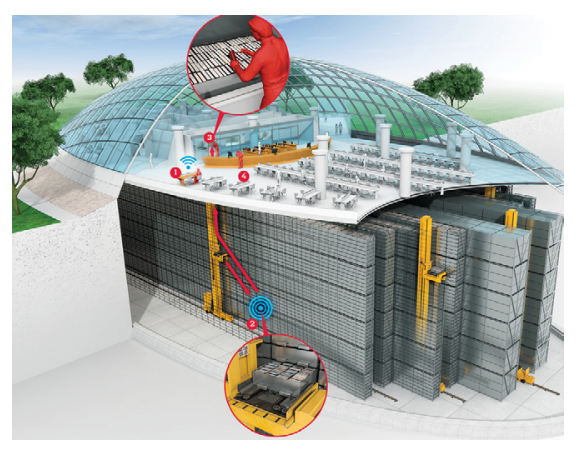

图 5 图书馆运转剖视 资料来源 : 参考文献 [8]

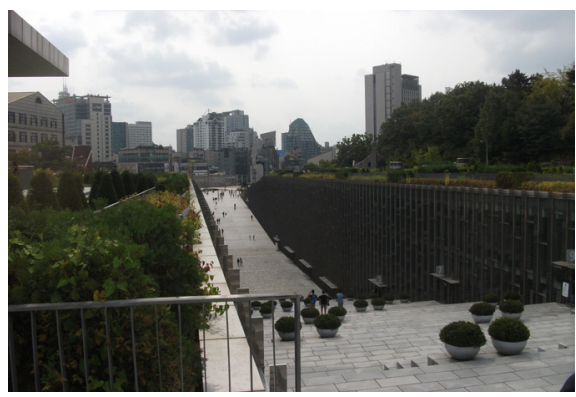

图 3 韩国梨花女子大学校园中心高点俯瞰 资料来源 : 赵景伟摄

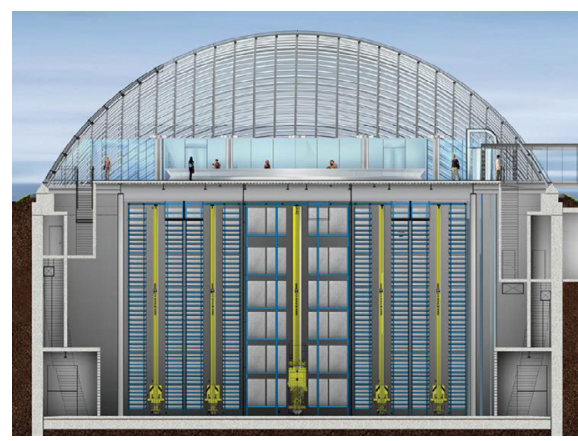

图 6 图书馆坚向剖面 资料来源 : 参考文献 [7] 
文与会议中心进行连通, 地面则完全恢复为景观绿地系统, 地下连通道顶部不规则造型的地面采光井在校园中庭绿地 上构成了丰富有趣的景观要素（图 11）。在该方案中, 建筑 单体不再是封闭独立式的, 而是通过空中走廊和地下通道 形成流动和开放的空间，成为联系人际、消除界线的触媒

（图 12）。体育馆量体以金属编网虚体与混凝土实体上下交 错而成, 区分大小跨距的运动空间属性; 图书馆却以前后量 体合抱来表现管理空间与阅览空间属性。两者借一凸一凹的 空中广场互相对话, 一动一静却展现和谐美感, 以相同特色 的外墙质感面对中庭绿地 ${ }^{[10]}$ 。

\section{5 高丽大学哈纳广场 ( Hana Plaza, Korea University )}

高丽大学 2004 年以前的哈纳广场区域是道路、停车及 绿化用地, 满足学生室外活动以及停车的功能要求。随着学 校规模的不断发展, 地面停车挤占了大部分学生的户外休息

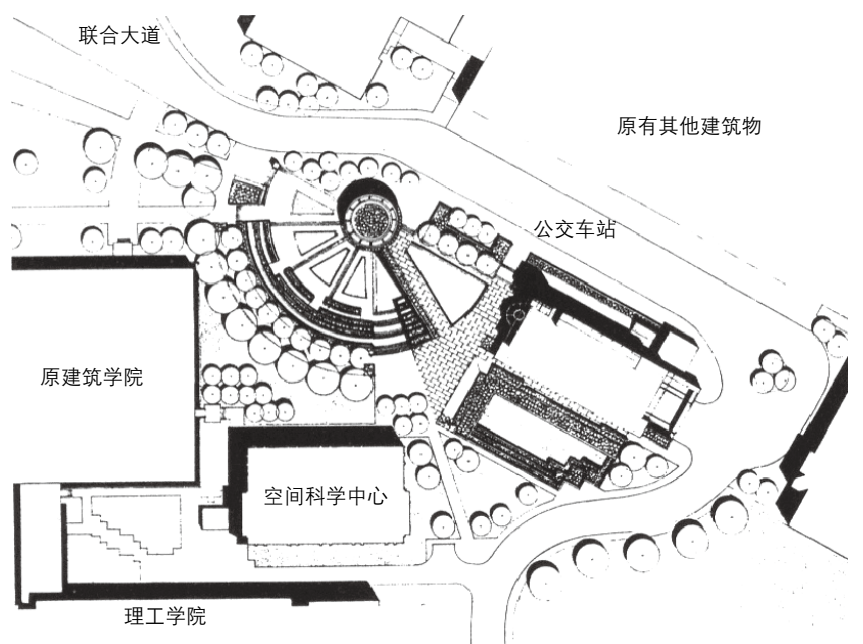

图 7 土木与矿物工程系新馆地面总平面图 资料来源 : 参考文献 [9]

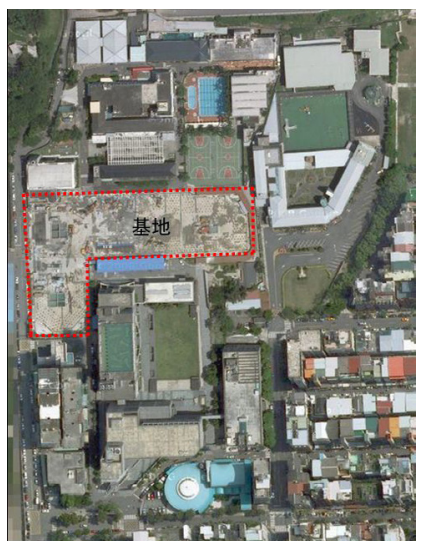

图 9 实践大学体育馆及图资大楼 施工平面

资料来源 : Google Earth（影像日期 200601-01)
和活动场地。学校的教育设施资源也日益紧张, 难以满足新 时期的功能需求。另一方面, 校园设施还应满足精神功能方 面的需求, 需要经过可持续性的设计, 创造具有艺术情趣和 景观设施的校园标志空间, 并且采用环保设计和技术以减小 对环境的影响。

为了解决这些问题, 高丽大学充分结合基础科学馆、理 学院大楼、生命与环境科学馆、科学图书馆、技术综合研究 中心之间的狭长开敞地带, 于 2004 年 11 月一2006 年 8 月建 设了建筑面积 $28155 \mathrm{~m}^{2}$ 的哈纳广场, 地下建设三层, 地面 除了满足开设地下空间出人口的需求外, 还通过大量的绿化及 景观设计创建了环境优美、舒适的地面花园（图 13一图 15）。 由于新建筑的主要功能是需要安静的教室和图书馆, 所以从 人体工程学角度而言, 地下空间更适合其功能要求。

该建筑物主要位于地下, 与普通建筑相比其隔热性能更 佳, 在严冬中的首尔可以节省至少 $30 \%$ 的供热成本。哈纳 广场地下建筑不仅包括服务学生的药店、美容院、邮政局、 银行、书店和食品店等, 还通过下沉广场的设计为地下空间 提供了令人愉悦的天然采光。尽管这个建筑物实际上是在地

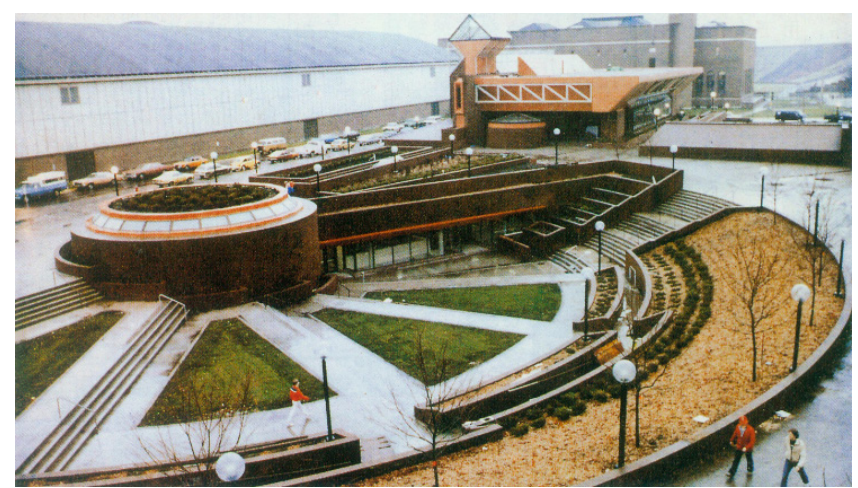

图 8 土木与矿物工程系新馆入口下沉广场 资料来源 : 参考文献 [9]

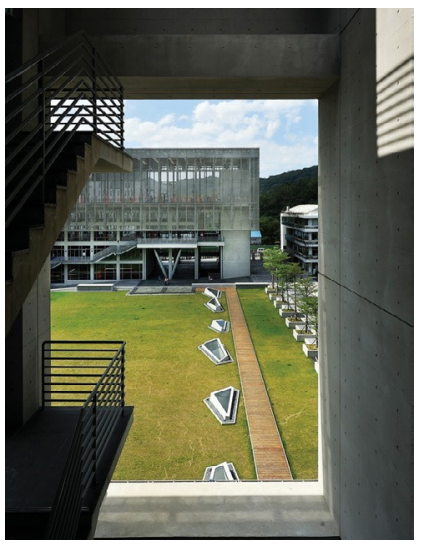

图 11 地下连通道的地面采光井 资料来源 : 参考文献 [10]

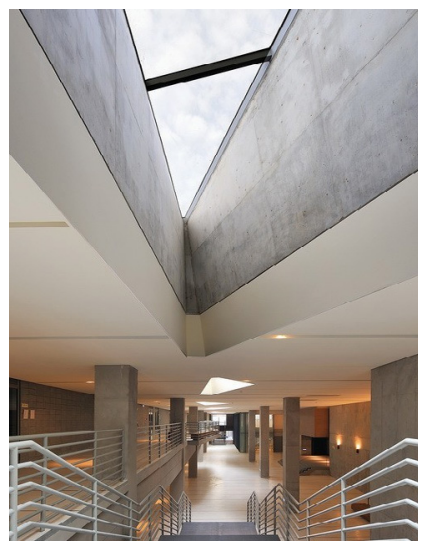

图 12 地下连通道之艺文会议中 心及顶部采光井 资料来源 : 参考文献 [10] 
下, 但是因为其与自然环境有直接的联系, 人们在里面并不 感觉是深处地下。大多数现有的停车位被移至地下, 地下车 库可以停车 526 辆, 而广场通过合理的景观设计作为绿化休 息区归还给学生。

\section{6 延世大学 Baekyang-ro 项目}

延世大学 (Yonsei University) 为了创造能够容纳各种教育 设施的新校园标志空间, 组织设计竞赛对校园的林荫大道进行 了重新设计 (图 15-17)。根据已实施的韩国 Samoo 建筑事务 所的方案, 地下建设三层, 总建筑面积达到 $58700 \mathrm{~m}^{2}$, 地面 全部为景观绿化设施用地, 地下停车库可停放机动车 917 辆, 地下建筑结构采用预应力钢筋混凝土结构, 建设时间为 2013 年 8 月一 2015 年 8 月。校区最初只有 $24 \%$ 的绿化空间, 建 筑密度约为 $50 \%$, 工程的主要难点在于将各个建筑最大限度 地用绿地连接起来, 因此也被称为 “绿色地毯”。

考虑到改造之前的路面标高低于周围的建筑物标高,

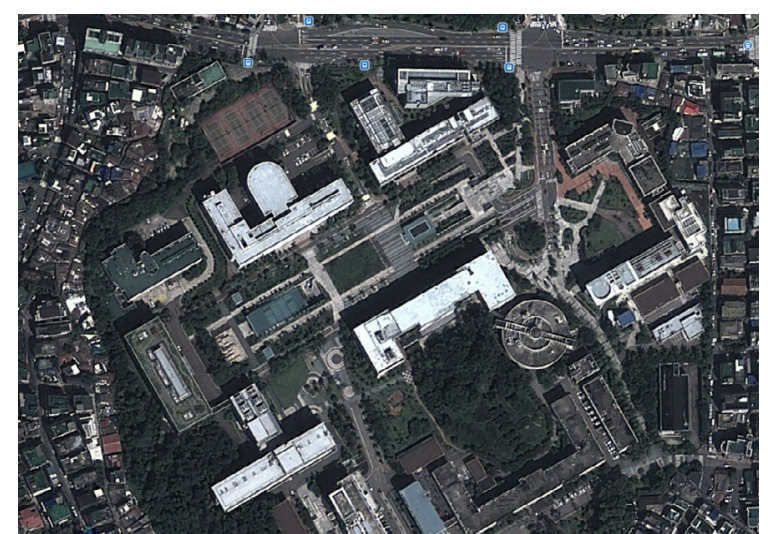

图 13 哈纳广场平面

资料来源：Google Earth（影像日期 2012-08-31）
Samoo 建筑事务所提出了一种三维循环设计方案 : 绿地公 园不仅能够方便地联系这些新的地下教育设施, 而且能够 与沿校园林荫大道分布的其他建筑物密切相连, 实现地上 地下三维空间的循环使用。为了将绿地比例增加到 $65 \%$ 以 上, 学生们的娱乐场所和停车场都要被转移至地下。设计 中由于对照明和空气循环采用了可持续的设计方法, 林荫 大道地下空间的条件非常接近于自然环境, 使进人空间的 人们精神愉悦。

\section{4 高校地下空间综合利用发展趋势}

作为城市系统重要组成部分的城市地下空间不仅仅是单 一层面上的空间构成，而且是在空间和时间上有机联系和相 互作用的产物, 是形态和功能复合开发的统一体。城市地下 空间开发利用是现代城市集聚效应和立体化、集约化发展的 要求, 地下空间开发与城市发展相互依存的关系在未来必然 更为紧密。

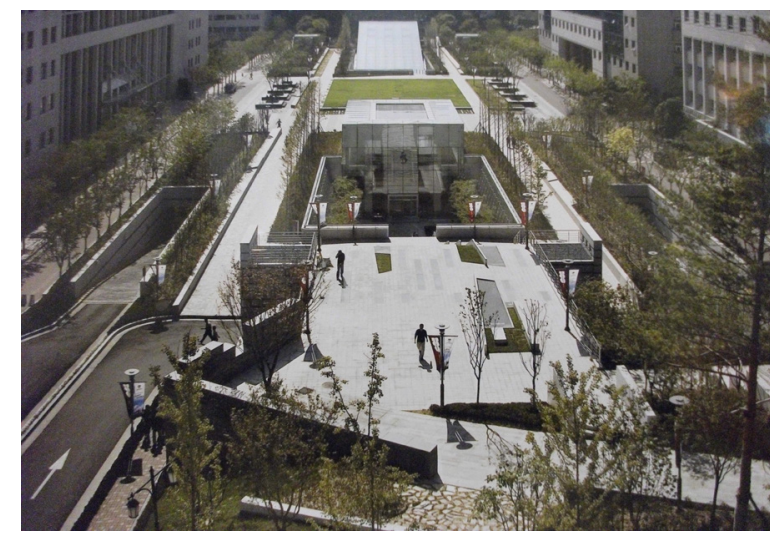

图 14 哈纳广场实景

资料来源: 赵景伟摄

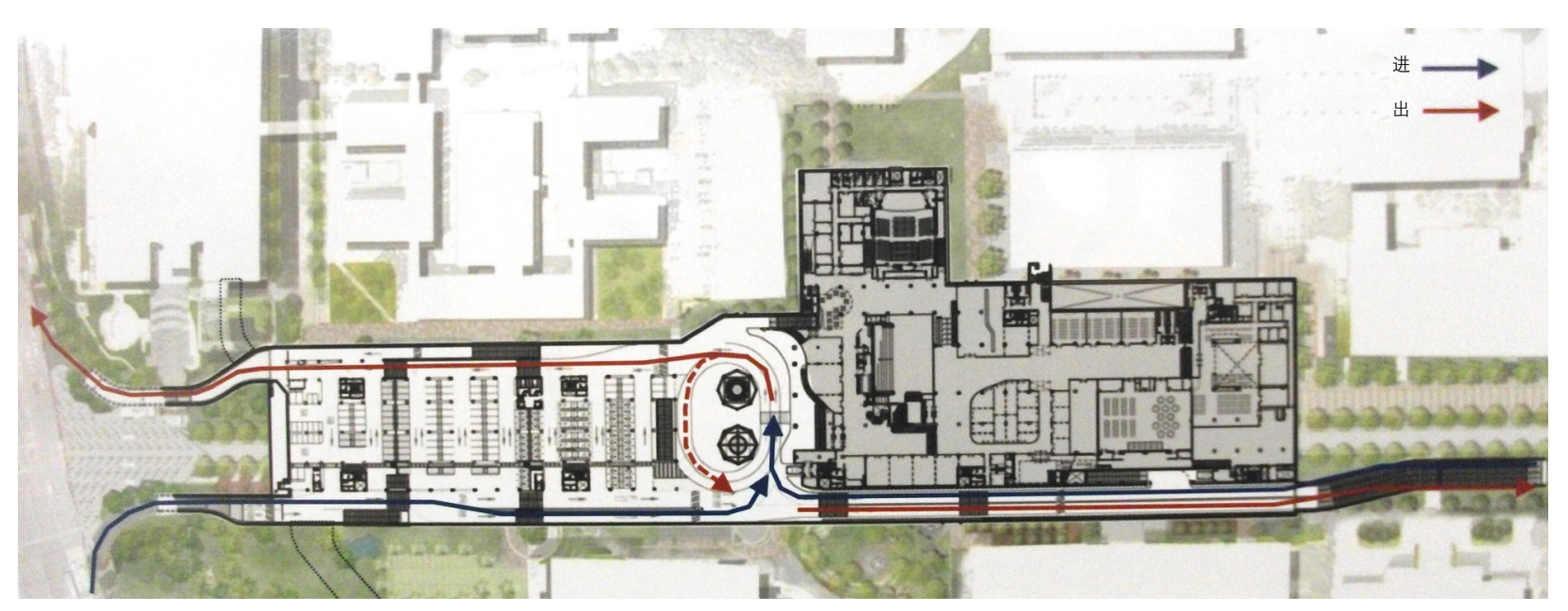

图 15 Baekyang-ro 项目地下一层平面图 资料来源 : 同图 2 
目前, 许多城市型高校都融人了现代城市空间, 其用地 结构、开发强度、环境整合等必然受到城市多种要素的影响。 与城市结构和生活交织在一起的大学, 特征是集中、高密度、 开放、步行化和功能混合 ${ }^{[11]}$ 。综合国内外高校的建设和发 展历程和经验, 我国高校校园地下空间综合利用发展趋势 如下。

\section{1 由 “自发小规模” 开发转向 “有计划大规模” 开 发, 注重扩充校园空间容量}

在国内大学校园规划建设的过程中, 采取建筑低密度外 延扩张的模式成为众多高校的首要选择, 这里不仅有城市政 府部门给予高校土地和政策优惠的诱导, 以及高校自身缺乏 建设资金, 还包含了某些高校盲目追求 “大校园、大景观、 大手笔” 的建设误区, 以及对自然、园林生态环境的极度 偏爱 ${ }^{[12]}$ 。这一时期的校园地下空间仅开发一些人防地下室、 教学实验室、后勤服务等简单功能的空间，规模小、自发性
强, 建设中缺乏对校园空间功能布局和空间组织关系的必要 研究, 各种设施零散分布不成体系, 内部空间通风和采光条 件较差, 利用率较低, 常常成为校园 “脏、乱、差” 甚至缺 乏安全感的空间区域。

自 20 世纪末以来, 高校的校园规模伴随着学生扩招经 历了前所未有的扩张, 直到 2006 年前后才逐渐在国家相关 政策的引导下稳定下来。许多高校通过对校园建设的科学分 析和规划论证, 借鉴了许多城市中心区空间的发展和整合模 式, 较多考虑了学校教学与科研的功能需求、校园环境的生 态需求、校园交通的动静态需求、学生业余生活的空间需求 等, 通过有计划、有目标地改造原有空间或新建的方式, 建 设了图书馆、公共服务设施、体育健身及娱乐设施、停车设 施、会议中心等规模较大、有代表性的地下空间建筑, 有效 地结合地面环境并通过合理开发地下空间扩充容量, 提高了 土地利用效率和环境效益（图 18, 图 19)。例如上海科技大 学新校区一期工程地下建筑面积达到 15 万 $\mathrm{m}^{2}$, 占校园总建

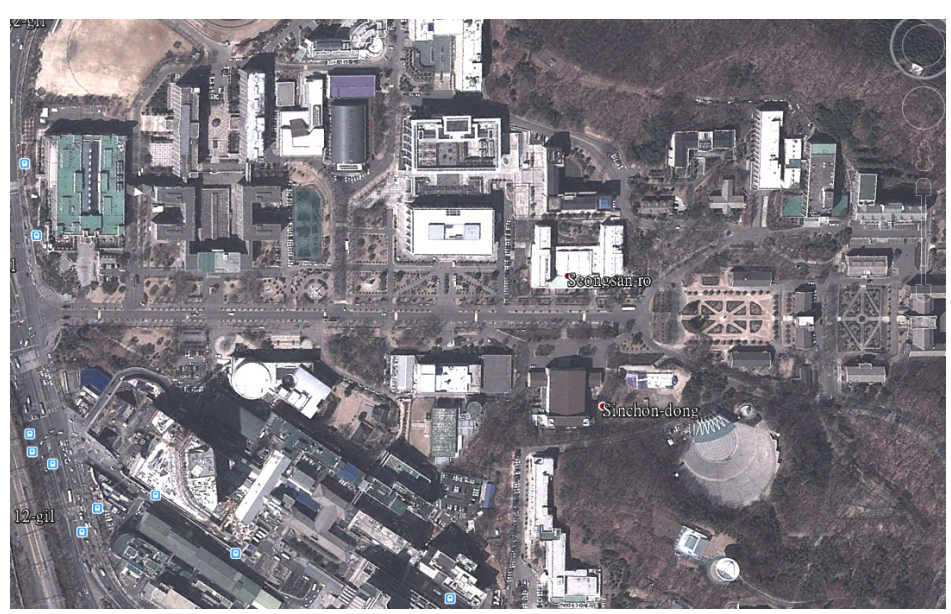

图 16 延世大学平面

资料来源：Google Earth（影像日期 2012-10-16)

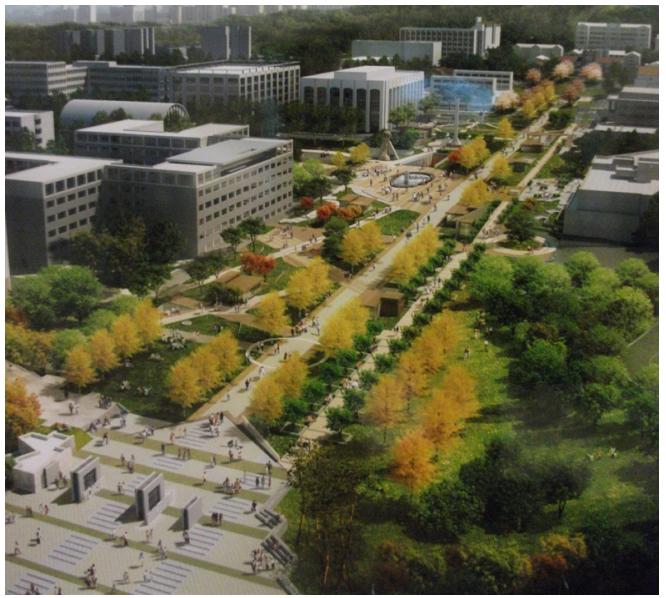

图 17 Baekyang-ro 项目鸟瞰图 资料来源：同图 2

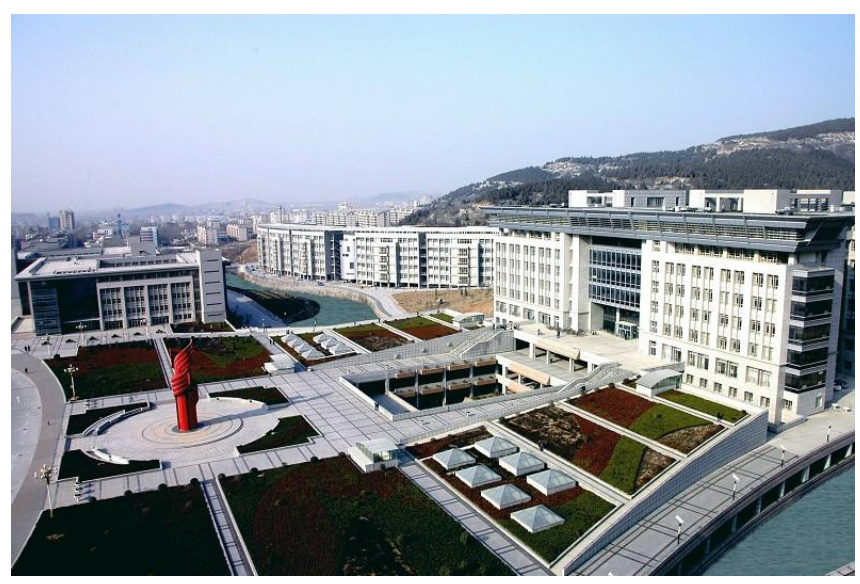

图 18 济南大学升华广场 资料来源 : 参考文献 [13]

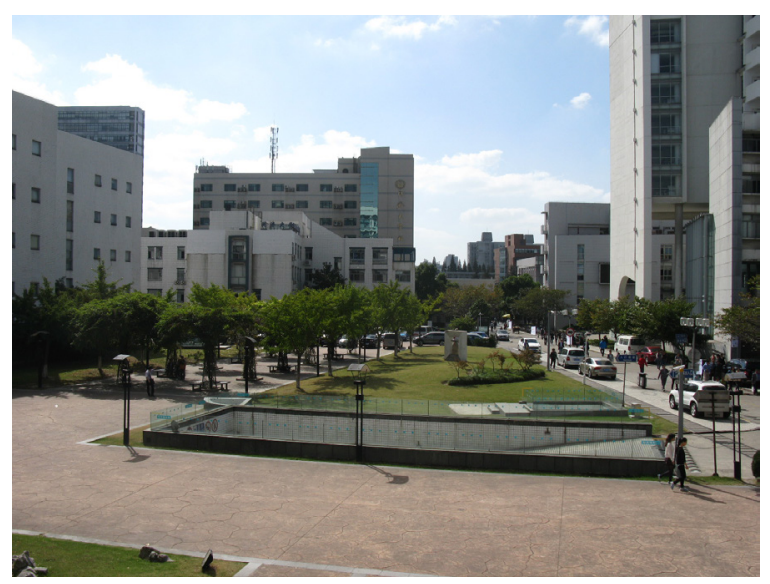

图 19 同济大学三叶草咖啡厅对面的地下停车库 资料来源 : 赵景伟摄 
筑面积的 $25.5 \%$, 在我国高校校园新建与改造工程中起到了 重要的示范作用。

\section{2 由单一功能转向多功能的校园地下综合体开发, 注 重校园功能复合性}

高校校园的整体运作效率与校园的功能布局和空间组织 关系、空间释放力和承载力, 以及师生的教学和生活内容的 契合度密切相关。进人 21 世纪后, 高校学生的业余生活日 益丰富多彩, 他们对美好事物和时代潮流的追求, 以及价值 观等方面都有了很大的转变。

高校里美食店、商店、咖啡店、药店、美容店、健身 馆、书吧等服务型设施越来越多, 种类越来越齐全, 满足了 广大学生在繁忙的课程学习之外交流、健身、休息和娱乐的 需求。这些设施是以高等教育为核心, 满足各种使用者物质 与精神需要的一种安排、布置和调度 ${ }^{[14]}$, 体现了现代高校空 间多功能发展的特点。在这一背景下, 高校地下空间开发也 由早期的单一功能转向多功能, 形成 “学习一生活一交往” 功能复合的校园地下综合体, 如新加坡管理大学 1.9 万 $\mathrm{m}^{2}$ 的地下温控中央大厅 (设有便利设施和设备, 包括办公室、 零售店面、庭院、一家诊所和大学健身房）以及前文提到的 韩国梨花女子大学校园中心、高丽大学哈纳广场、延世大学 Baekyang-ro 项目等。新加坡国立大学和南洋理工大学目前 也正在进行校园地下综合体（综合图书馆、自习室、餐厅、 博物馆和会议室等)、地下体育馆和实验室等项目的研究。

此外, 由于地下空间对多种灾害具有较强的防护功能, 因此在建立城市综合防灾体系的过程中, 应将高校校园多功 能型地下空间纳人整个城市的综合防灾体系中, 在战时可以 转换为指挥通信、医疗救护、专业停车、人员掩蔽（专业队 和一般人员) 、后勤物资库等场所, 发挥防灾减灾及应急避 难的重要功能, 有效节约人防建设资金, 提高城市的总体抗 灾抗毁能力。

\section{3 由单一建筑型转向多建筑连通型的地下空间开发, 注重校园地下连通性}

校园需要满足其活动主体（大学生）的功能性活动与生 活性活动的综合需求, 通畅的地下通行系统不仅能将校园生 活区与功能区连接起来, 增强各个功能区的可达性, 而且能 够保护师生在行走时免受风雨日晒的煎謷, 缩短步行距离, 保证校园整体的高效与有序。

目前, 在土地资源紧缺的新加坡大学中, 已经进行或正 在研究利用地下空间连通多个地面教学建筑的计划和方案, 例如新加坡管理大学已经在 2005 年通过地下中央大厅的建 设, 打通了学校主要地上建筑之间的联系, 并将 5 栋主建筑
和附近的勿拉士峇沙（Bras Basah）火车站打通。前文所提 到的台北实践大学体育馆及图资大楼也是地面校园建筑在地 下连通的成功案例。

\section{4 由静态交通转向动、静态交通综合, 注重校园高效 联络}

随着私家车在我国的进一步普及, 高校校园内机动车拥 有量也急剧增加, 校园内人车矛盾日益突出, 带来了两个方 面的问题: 首先, 机动车数量迅速增长, 原有地面停车设施 不足, 机动车挤占校园道路, 使校园交通状况在高峰时段恶 化; 其次, 由于高校内机动车行驶与学生步行空间存在很大 程度的重叠, 不少高校为了缓解机动车的影响, 防止上下课 学生行走高峰期间出现交通事故, 对机动车采用限制行驶或 规定特定路线行驶的方法, 却收效甚微。

从城市全局看, 交通问题严重制约着城市空间的有效利 用, 而集约化、立体化的交通，特别是地下交通系统在城 市空间发展中具有重要的作用。在城市中心区交通最紧张 的主干道路下开发地下公路 (立交) 隧道是有效解决城市 交通问题的方法。遵循城市交通的立体化发展趋势, 结合 校园广场、操场、建筑物、绿地修建地下停车库, 采取 “人 车分离” 和 “步行者优先”的思路, 打通全部或局部校园 主干道地下空间, 满足车辆行驶的需要, 留出更多的开敞 空间用于绿化和美化, 可有效解决校园内人车混行所带来 的复杂问题。

韩国梨花女子大学校园中心最下面两层建设为停车库, 车辆可以通过两条专用地下车行道从外界直接进出车库, 很 大程度上减少了机动车对地面行人的影响, 不仅提高了车辆 的停放效率, 而且保障了地面行人的安全, 改善了校园景观。 上海科技大学为了解决校园机动车的停放和内部联络问题, 采用集中模式建设校园地下车库系统, 选择校园停车和机动 车交通较为聚集的区域进行地下空间整体开发 (图 20), 构

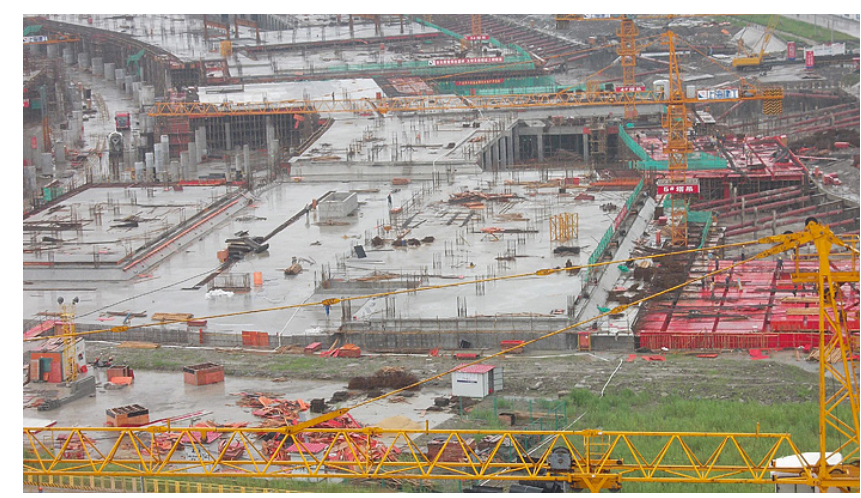

图 20 上海科技大学地下工程施工现场

资料来源 : 参考文献 [16] 
建地下环路系统（长约 $1.8 \mathrm{~km}$ ), 衔接地下停车泊位约 1600 个, 配置了 5 对出人口联系各个方向, 实现了校园各功能区 地下交通的高效联络和地下停车泊位的高度共享 ${ }^{[15]}$ 。

\section{5 结语}

与 20 世纪相比, 现代城市型高校校园功能空间出现了 许多变化。高校校园不仅融合了所在城市的部分功能, 在交 通、娱乐、休闲、游览参观等方面为城市提供更多的功能性 空间, 而且其内部也出现了许多服务于师生的地下便利设施 和设备, 包括办公、教室、停车、美食、零售、咖啡店、药店、 庭院、美容店、书吧、诊所和健身房等。

高校校园通过开发地下空间、整合校园空间功能, 能够 使校园获得更为丰富的空间资源，促进空间的集约化利用， 改善校园地面空间的生态和交通环境, 有利于实现土地资源、 服务设施、基础设施的共享, 降低校园运行的能源和资源成 本, 提高空间发展的可持续性。

在有地下空间建设需求和建设条件的高校中, 可考虑设 立与地下空间开发利用、建设、管理的相关研究机构或专业 管理部门，采用广泛的集资渠道，充分挖掘地下空间潜力资 源, 研究地下空间开发利用规模和容量的规划技术指标、不 同地形地貌特征下的地下建筑设计方法, 提高校园土地利用 效率和空间容纳效率。通过为高校师生构建一个高质量的学 习和生活环境, 完善各种教学与服务设施以及良好的建筑设 计及交通设施，来保障高校校园空间的可持续发展。UP

\section{参考文献}

[1] 黄翼, 吴硕贤.我国高校校园规划设计发展趋势探析 [ J ] 城市规划, 2014, 4: 85-91.

[2] 雷雨.广州大学城 10 年 “变身” 进驻大学生数量翻两番 [N]. 南方日报, 2014-09-01(A09).

[3] 崔海波. 我国大学城建设对城市空间结构的影响研究—以广州大学 城为例 [D]. 华南师范大学, 2007.

[4] 吴正旺, 王伯伟. 大学校园规划 100 年 [J]. 建筑学报, 2005, 3: 5-7.

[5] 高冀生. 中国高校校园规划的思考与再认识 [J]. 世界建筑, 2004, 9: 76-79.

[6] 吴恽, Miyamoto Funito. 城市空间和大学校园一以日本国立大学校 园空间变迁为例 [J]. 学术探索, 2013, 12: 123-126.

[7] 独具匠心：美国芝加哥大学曼索托图书馆设计 [EB/OL]. 土木论坛 (2013-10-10)[2014-12-26]. http://bbs.co188.com/thread-8759137-1-1.html.

[8] Kalee Thompson, How It Works: Underground Robot Library[EB/OL] Popular Science. (2012-03-10)[2014-12-26]. http://www.popsci.com/ content/underground-robot-library.

[9] 童林旭. 地下建筑图说 100 例 [M]. 北京: 中国建筑工业出版社, 2007 28-29.

[10] 姚仁喜. 实践大学体育馆及图资大楼 [J]. 建筑学报, 2013, 4: 38-45

[11] 陈晓恬.中国大学校园形态演变 [D]. 同济大学, 2008 .

[12] 吴正旺, 杨拿, 王晓博. 结合景观与绿化的北方高校地下空间 [J]. 新建 筑, 2013, 4: 105-108.

[13] 济南大学校园风光 [EB/OL]. 济南大学. [2014-12-20]. http://news.ujn. edu.cn/campus_scenery/.

[14] 郑明仁. 大学校园规划整合论 [J]. 建筑学报, 2001, 2: 59-64.
[15] 黄平. 大学校园综合交通规划研究新思路——上海科技大学地下空 间规划为例 [J]. 交通与运输, 2013, 2: 87-90.

[16] 园区建设 - 工程进展 [EB/OL]. 上海科技大学. [2014-12-16]. http:// www.shanghaitech.edu.cn/construct/progress/48.html\#ad-image-26.

(本文编辑：张神娴)

\section{更 正 启 事}

本刊 2016 年第 5 期 “实践综述” 栏目中《日本乡 村振兴中价值观层面的突破: 以能登里山里海地区为 例》一文，因排版原因导致基金信息出现错误，第 115 页基金信息应予以删除。

此外, “城市研究”栏目中《新时期我国主要中心 城市走向 “全球城市” 的路径研究一一基于 “中心度一 联系度” 的辨析和讨论》一文, 第 50 页致谢中的 “徐 云博士研究生” 应为 “徐素博士研究生”。

特此向作者和读者致歉。 